\title{
Economic European Integration: Assessment and Modelling of Superficial and Hidden Factors of Divergence Between Ukraine and the EU
}

\section{YEVHENII REDZIUK ${ }^{1}$}

\begin{abstract}
The article analyses the current European integration processes and measures implemented by Ukraine over the past five-six years in terms of its social and economic development. The study has shown that Ukraine's involvement in European integration processes has questioned the economic performance of the domestic economy sector, the wealth of Ukrainian citizens, infrastructure upgrade and industrial re-equipment. The Agreement on Deep and Comprehensive Free Trade Area with the EU countries, signed and implemented by Ukraine, has not had a critical impact on the improvement of Ukraine's leading macroeconomic indicators. Thus, the GDP recovery, investment and infrastructure renewal rate was very low, with depressed and unstable social and economic projects in 2014-2019; in general, this prevented from moving toward the EU standards. It is also noted that with the growth of EU's GDP by USD 1, the foreign trade turnover of all goods will increase by USD 0.887, and bilateral turnover of agricultural and industrial goods - by USD 1.693 dollars; Ukraine's GDP growth has a much smaller impact, which can be explained by the difference in the EU and Ukrainian economic scales. Based on modelling study, forecasting and analysis of time series within the last five-six years, it is proved that without regular investments, supporting measures to trigger the development of high-tech sectors of Ukraine's economy and without its production and logistics partnership and involvement in the global most powerful economic centres, the domestic social and economic segments will continue to worsen and be exposed to the globalized economic risks. Therefore, it is proposed to develop new approaches to the European integration process based on pragmatism and successful experience of Central and Eastern European countries, namely to implement the relevant measures and a strategic level program in Ukraine to propel and develop high-tech and high-margin industrial sector. This requires triggering of state policy on strong involvement of co-financing of structural funds, as well as EU's framework and targeted programs; attracting investment, reducing the influence of oligarchic clans and corruption on the social and economic system of Ukraine. In addition, it is urgent to launch a strategic level program in Ukraine to develop a policy with priority initial stage focusing the key resources on the development of IT sector, which can a priori be integrated and rapidly developed in course of implementation of EU's current industrial innovation strategy.
\end{abstract}

KEY WORDS: economic European integration, economy sector of the EU and Ukraine, social and economic development of European countries, international economic relations, global economy.

\section{Introduction}

Integration economic unions, which guarantee domestic economies the respective tools of institutional, financial and economic support, increase

\footnotetext{
* This article was translated from its original in Ukrainian.

${ }^{1}$ Redziuk Yevhenii Vasilovich - Candidate of Economic Sciences, Associate Professor, Senior Research Fellow, Institute of Economics and Forecasting of the National Academy of Sciences of Ukraine. Sphere of scientific interest: European and international economic integration, globalization of economic development, international investment, international finance and trade. E-mail: redzyuk@gmail.com
}

IEP, No. 34 (2021), pp. 91-114

(c) Yevhenii Redziuk, 2021 «All rights reserved»

ISSN 1811-9832/2021/No. 1 (34) 
their resilience to external negative influences, simplify and improve intraintegration interstate flows of resources, including investment, human and manufacturing resources. In general, integration economic unions contribute to more regular and powerful social and economic growth of each country through cooperation and reduction of overhead costs, restrictions and prohibitions. However, in the case of Ukraine, its measures aimed at involvement in European integration processes, unfortunately, did not have a clear positive impact on economic development indicators, the wealth of Ukrainian citizens, significant infrastructure upgrades and industrial reequipment.

It should be noted that within the current five-six years of Ukraine's European integration efforts, there are relevant indicators, data and trends, which allow to comprehensively assess this process, identify hidden and superficial factors of divergence between Ukraine and EU countries, rethink the current state of Ukraine effective approaches and steps made toward the European integration processes.

A number of scientists analysed the social and economic European integration between Ukraine and the EU countries: T. Bohdan, O. Borzenko, I. Burakovskyi, T. Burlai, V. Heyets, T. Kachka, Hzh. Kolodko, D. Lukianenko ${ }^{2}$ V. Sidenko, J. Stiglitz, A. Filipenko, O. Sharov, O. Shnyrkov ${ }^{3}$, etc. These scholars made a significant contribution, but the Ukraine's European integration requires rethinking, regular assessment, identification of relevant patterns and hidden factors of divergence between Ukraine and EU countries; this will ensure forecasting of the further development and prospects of Ukraine in the process of European integration.

This article is aimed to indicate the actual Ukrainian social and economic patterns and explore their transformation in course of Ukraine's European integration efforts, make a forecast and provide reasonable recommendations on the best ways to develop the domestic economy sector.

\section{Background and framework of Ukraine's European integration}

At the current stage of the globalized economy sector, it shows the exponential growth rate. Within $1900-2020$, the global GDP increased in 36.4 times (from USD 3.42 trillion to 124.3 trillion). At the same time, even with due consideration to the bad influence of the COVID-19 pandemic in 2020 on the global economy sector, within next 2021-2022 experts forecast

\footnotetext{
${ }^{2}$ Lukianenko D., Chuzhykov V., Wozniak M., Antoniuk L. Convergence and Divergence in Europe: Polishand Ukrainian Cases / Monograph. - K.: KNEU. (2013). - 688 p.

${ }^{3}$ Shnyrkov O. O., Ivkova N. I. Porivnialna kharakterystyka vnutrishno haluzevoi torhivli Ukrainy z YeS za indeksom Hrubelia-LLoida / Aktualni problemy mizhnarodnykh vidnosyn. (2018). — Vypusk 136. - S. 84-92. [In Ukrainian].
} 
ECONOMIC EUROPEAN INTEGRATION: ASSESSMENT AND MODELLING OF SUPERFICIAL AND HIDDEN FACTORS OF DIVERGENCE BETWEEN UKRAINE AND THE EU

the further rapid GDP growth and global population. Current regional and international free trade agreements contribute to the regular global economy growth, and the vast majority of countries join certain regional and international agreements if they consider them beneficial ${ }^{4}$.

By signing relevant association agreements, the European Union (EU) offers its trading partners the deepest level of cooperation available to third countries. Ukraine's signing of the Association Agreement, which contains provisions on a deep and comprehensive free trade area with its subsequent full implementation, confirms the one-way European vector of Ukrainian development and adoption of the development European model. This can be the reason for regular and comprehensive institutional and legal, social and political, financial and economic and social and demographic upgrading of the domestic economy sector. Still, a comprehensive and deepened free trade area should facilitate Ukraine's gradual integration into the EU's internal market and system of standards.

On June 27, 2014, Ukraine signed the economic part of the Agreement, which ensures the free trade area. The EU decision to abolish and reduce 98 percent of customs rates for Ukrainian exports entered into force on April 22, 2014. On September 16, 2014, the Association Agreement between Ukraine and the EU was ratified by the Verkhovna Rada and the European Parliament. The Association Agreement, which contains the provisions of the Deep and Comprehensive Free Trade Agreement (DCFTA), in full entered into force on September 1, 2017, although some parts came into force on November 1, 2014, while the provisions of the DCFTA Agreement - from January 1, 2016. Thus, the introduction of a free trade policy with promising trade and economic partners supports Ukrainian efforts to diversify the location vector and range of national exports in the long run.

The agreements within the framework of the Free Trade Area with the EU ensure a number of advantages and threats. Thus, the implementing tools of the opportunities of the free trade area between Ukraine and the EU contributes to the deepening of trade integration and entry of domestic producers into one of the most high-margin markets (types of markets where goods are in high demand; there is a high level of customers' solvency, which leads to high added value of producers of these goods); introduction of value chains within the Ukraine-EU DCFTA; attracting investment for introduction and upgrading of manufacturing facilities; implementation of horizontal, concentric and conglomerate diversification; improving energy efficiency and re-equipment; supplies of quality and affordable imports; grabbing by domestic businesses the third country markets.

\footnotetext{
${ }^{4}$ Vlasiuk V. Ekonomichne vidrodzhennia cherez industrialnyi rozvytok Ukrainy. — Kharkiv: Povnokolir, 2020. - 432 s. [In Ukrainian].
} 
At the same time, there are threats caused by differences in the economic development level of the countries; market scale; countries' degree of integration into the global economy increasing the disbalance of trade integration. The key threats are increasing competitive pressure on domestic business; continued trade war with the Russian Federation, which led to the introduction of mutual sanctions, trade barriers and embargoes. The current exports and imports pattern highlights a dangerous manufacturing imbalance for Ukraine: raw material imports from Ukraine and high-tech EU exports; maintaining a negative balance in foreign trade for most groups of goods; limited access of domestic businesses to the EU market due to the high level of non-tariff protection, primarily for industrial and agricultural products.

\section{General estimation of trade integration between Ukraine and the EU}

Bilateral trade integration as a result of the implementation of a deep and comprehensive free trade area led to renewal of Ukraine's trade policy. The key focus was made on: growth of trade turnover between countries and growth of the share of European countries within Ukraine's foreign trade segment; reduction of import duties; improving market access conditions; legislation adjustment; fixing of tariff rate quotas; significant reduction of non-tariff barriers to trade; agreements of countries on improving the customs procedures; adjustment of technical regulation policy; adjustment of standardization, metrology, conformity assessment and market surveillance policies; adjustment of sanitary and phytosanitary measures; strengthening the protection of intellectual property rights.

Forecasting and modelling study of the foreign trade turnover between Ukraine and the EU in general, and agricultural and industrial products in particular, based on the use of the gravity model (gravity equation is a derived equation when trade between two countries is directly proportional to the scale of their economies and inversely proportional to the distance between them (1).

$$
F_{i g}=G \frac{M_{i}^{a} M_{i}^{B}}{d_{i j}^{\delta}} \varepsilon_{i j}
$$

where $F_{i g}$ is the trade turnover between countries i та $j ; M^{a}{ }_{i}$ and $M^{B}{ }_{i}-$ gross domestic product of countries $\mathrm{i}$ and $\mathrm{j} ; \mathrm{d}^{\delta}{ }_{\mathrm{ij}}$ - factor of trade costs, including logistics costs; $\varepsilon_{\mathrm{ij}}-$ all other factors that influence turnover, but are not included in the equation; $\alpha, \beta, \delta$ - constants (model parameters).

The gravity equation shows that there is a clear impact of economic growth in EU's GDP. Thus, with the growth of EU's GDP by USD 1, 
ECONOMIC EUROPEAN INTEGRATION: ASSESSMENT AND MODELLING OF SUPERFICIAL AND HIDDEN FACTORS OF DIVERGENCE BETWEEN UKRAINE AND THE EU

foreign trade turnover of all goods will increase by USD 0.887, while bilateral trade in agricultural products - by USD 1.693. The impact of Ukraine's GDP has a much smaller impact; this can be explained by the difference in scales of the EU and Ukrainian economies. With the growth of Ukraine's GDP by USD 1, foreign trade turnover increases by USD 0.848 , while bilateral turnover of agricultural products - by USD 0.358. As for the oil price, the increase in the oil price contributes to the growth of trade between countries, although according to the gravity model there should be an opposite effect. This phenomenon can be explained by the fact that the EU countries are located not far from each other, and transportation is not a key part of the costs, which, accordingly, is not so important for trade between countries. The Free Trade Area (FTA) between Ukraine and the EU has played an important role in increasing trade between the countries as of 2015-2020, as it guaranteed Ukraine's exports and imports increase with EU countries. The key share of trade preferences falls on agricultural products, as due to a significant increase in turnover of agricultural products the Ukraine's total turnover is growing. In general, Ukraine needs to have a more significant sector on both European and global economic map; this includes more pragmatic policy of integration and implementation of a strategy of gradual increase in domestic economic facilities.

In recent years, Ukraine and most of emerging market countries faced the spiralling dependence of economic growth on exports due to the domestic underdeveloped market and low effective demand within the country. Exports from Ukraine to the EU are expected to show a robust growth, to USD 22,503.8 million in $2022^{5}$.

By joining the WTO in 2008 and signing a free trade agreement with the EU in 2014, Ukraine has opened up to international competition failing to prepare the manufacturing sector. The sector was low-tech with no supporting tools prevailing at the developed countries, including the EU. As a result, the domestic mining and metallurgical sector still continues to export ore and ferrous metals, semi-finished products and steel products, agricultural products - grain, oil, rapeseed, i.e. low-added value products; the segments of the electrical industry, mechanical engineering, chemical and automobile industry began to disappear. Having lost a significant share of the processing sector, Ukraine's economy has undergone structural simplification and significantly weakened recovery opportunities for sustainable growth. The small scale of Ukraine's economy is both a cause

\footnotetext{
${ }^{5}$ Балежентіс A., Яценко О. Асиметрії торговельної інтеграції України та ЄС // Міжнародна економічна політика. — К. (2018). — № 1 (28). - C. 32-62
} 
and a result of its structural simplification. First of all, it generates too little money for expanded economic reproduction ${ }^{6},{ }^{7}$.

European integration processes have worsened Ukrainian economy framework in a quality manner, simplified it by targeting raw material focus, worsened the innovative economic reproduction, cooperation and manufacturing, investment and infrastructure background.

\section{Analysis of the key macroeconomic indications of Ukraine within the active European integration period (2014-2019)}

Within the past five-six years, investment indications of Ukraine confirm these trends. Thus, within nine months of 2020, capital investments in Ukraine were made by own funds of the companies and reached 69.2 percent, and by foreign investors -0.5 percent. In general, within the recent years, foreign direct investment (FDI) has not significantly affected the transformation of the social and economic segment of Ukraine (Table 1).

Table 1

DIRECT INVESTMENTS FROM WORLD AND EU COUNTRIES IN THE ECONOMY OF UKRAINE, MILLION USD ${ }^{8}$

\begin{tabular}{|l|c|c|c|c|c|}
\hline & 2015 & 2016 & 2017 & 2018 & \multicolumn{1}{c|}{2019} \\
\hline Total FDI in Ukraine & $32,122.5$ & $31,230.3$ & $31,606.4$ & $32,905.1$ & $35,809.6$ \\
\hline Total FDI from EU countries & $24,982.8$ & $23,425.7$ & $24,145.2$ & $25,972.3$ & $28,289.3$ \\
\hline $\begin{array}{l}\text { Total FDI from EU-15 } \\
\text { countries }\end{array}$ & $13,347.9$ & $12,936.9$ & $13,400.8$ & $14,475.1$ & $16,029.7$ \\
\hline $\begin{array}{l}\text { Total FDI from EU countries } \\
\text { less offshore countries } \\
\text { operations }\end{array}$ & $6,952.5$ & $6,538.4$ & $6,806.5$ & $7,093.5$ & $7,339.3$ \\
\hline
\end{tabular}

Table 1 summarizes that the Ukrainian economy has not attracted significant investments, neither from different countries, nor from EU

\footnotetext{
${ }^{6}$ Власюк В. Економічне відродження через індустріальний розвиток України. — Харків: Повноколір, 2020. $-432 \mathrm{c}$.

${ }^{7}$ Lukianenko D., Chuzhykov V., Wozniak M., Antoniuk L.Convergence and Divergence in Europe: Polish and Ukrainian Cases / Monograph. - K.: KNEU. (2013). - 688 p.

${ }^{8}$ Official site of the State Statistics Service of Ukraine / URL: http://www.ukrstat.gov.ua/

${ }^{9}$ To determine the indicators, the author did not calculated the indicators of Cyprus, Austria, the Netherlands, $1 / 2$ the United Kingdom of Great Britain and Northern Ireland, which include such offshore centers as the Isle of Man, Guernsey, Alderney, Jersey, etc. In these countries, there is a significant activity of Ukrainian firms in financial services that are not related to traditional banking (currency purchase, lending, insurance).
} 
ECONOMIC EUROPEAN INTEGRATION: ASSESSMENT AND MODELLING OF SUPERFICIAL AND HIDDEN FACTORS OF DIVERGENCE BETWEEN UKRAINE AND THE EU

countries. Note that net FDI in Ukraine amounted to: 2014 - USD 0.41 billion, 2015 - USD 4.322 billion, 2016 - USD 4.406, 2017 - USD 2.511 billion, 2018 - USD 2.802 billion, 2019 - USD 2.531 billion. In 2020, FDI is expected at USD 1.5-2 billion. Within these years, the investments reduced by $3-4$ times comparing to record-breaking FDI in the economy of Ukraine in 2007-2008, when FDI were USD 8-10 billion). In 2010-2013, FDI in the economy of Ukraine also amounted to USD $4-7.2$ billion. In addition, there are significant reductions in FDI in the economy of Ukraine in 2017-2020, which, in our opinion, is due to the primitivization and structural simplification of domestic industries, reducing the share of manufacturing, engineering, chemical, pharmaceutical industries and increasing metallurgical and mining, agriculture, forestry sectors, which do not require significant investment in cutting-edge technologies, equipment, industrial cooperation, scientific and technical, design services, etc.

The author's assumptions are confirmed by the relevant statistics on FDI in the economy of Ukraine by type of business activity (Table 2).

Table 2

DIRECT INVESTMENTS FROM WORLD AND EU COUNTRIES IN THE ECONOMY

OF UKRAINE BY TYPE OF BUSINESS ACTIVITY (TOP-5 FIELDS), MILLION USD ${ }^{10}$

\begin{tabular}{|l|c|c|c|c|c|}
\hline & 2015 & 2016 & 2017 & 2018 & 2019 \\
\hline Processing industry & $7,531.9$ & $7,523.9$ & $7,999.9$ & $8,337.6$ & $8,609.3$ \\
\hline $\begin{array}{l}\text { Wholesale and retail trade; } \\
\text { repair of motor vehicles and } \\
\text { motor bikes }\end{array}$ & $5,247.4$ & $5,106.5$ & $4,957.8$ & $5,480.2$ & $5,662.5$ \\
\hline Financial and insurance sector & $4,350.1$ & $3,627.4$ & $3,526.3$ & $3,641.1$ & $4,557.6$ \\
\hline Real estate transactions & $3,882.1$ & $3,764.4$ & $3,796.3$ & $4,258.2$ & $4,495.7$ \\
\hline $\begin{array}{l}\text { Manufacture of food products, } \\
\text { beverages and tobacco }\end{array}$ & $2,419.0$ & $2,530.5$ & $2,758.4$ & $2,859.4$ & $2,844.3$ \\
\hline
\end{tabular}

Table 2 shows that FDI in the processing industry is $1.7-2$ times less than unearned sector (which does not produce value-added products, but operates through commissions / financial and insurance activity / and various allowances / trade, real estate) and raw materials and agricultural field. There is no strong increase in investment in any priority industries or business segments. The state of industrial infrastructure in Ukraine without

${ }^{10}$ Official site of the State Statistics Service of Ukraine / URL: http://www.ukrstat.gov.ua/ 
investment is suffering and needs significant renewal, but this is mainly carried out by domestic enterprises and organizations. In Q1 2020, capital investment at their expense amounted to UAH 56.294 billion (at the expense of foreign investors - UAH 0.514 billion); in Q2 2020 - UAH 113.038 billion (at the expense of foreign investors - UAH 0.846 billion); in Q3 2020 - UAH 185.496 billion (at the expense of foreign investors - UAH 1.299 billion $)^{11}$. Within $2014-2019$, there are also no significant changes in capital investment by sources of funding (Table 3 ).

Table 3

CAPITAL INVESTMENT BY SOURCES OF FUNDING IN 2014-2019, MILLION UAH ${ }^{12}$

\begin{tabular}{|c|c|c|c|c|c|c|}
\hline & 2014 & 2015 & 2016 & 2017 & 2018 & 2019 \\
\hline Total & $219,419.9$ & $273,116.4$ & $359,216.1$ & $448,461.5$ & $578,726.4$ & $623,978.9$ \\
\hline \multicolumn{7}{|l|}{$\begin{array}{l}\text { including at the } \\
\text { expense of: }\end{array}$} \\
\hline state budget funds & $2,738.7$ & $6,919.5$ & $9,264.1$ & $15,295.2$ & $22,814.1$ & $30,834.5$ \\
\hline local budget funds & $5,918.2$ & $14,260.0$ & $26,817.1$ & $41,565.5$ & $50,355.5$ & $56,480.0$ \\
\hline $\begin{array}{l}\text { own funds of } \\
\text { enterprises and } \\
\text { organizations }\end{array}$ & $154,629.5$ & $184,351.3$ & $248,769.4$ & $310,061.7$ & $409,585.5$ & $408,275.7$ \\
\hline $\begin{array}{l}\text { bank loans and } \\
\text { other loans }\end{array}$ & $21,739.3$ & $20,740.1$ & $27,106.0$ & $29,588.9$ & $44,825.4$ & $67,232.6$ \\
\hline $\begin{array}{l}\text { funds of non- } \\
\text { resident investors }\end{array}$ & $5,639.8$ & $8,185.4$ & $9,831.4$ & $6,206.4$ & $1,795.5$ & $4,663.9$ \\
\hline $\begin{array}{l}\text { funds of } \\
\text { population for } \\
\text { housing } \\
\text { construction }\end{array}$ & $22,064.2$ & $31,985.4$ & $29,932.6$ & $32,802.5$ & $34,645.7$ & $32,422.0$ \\
\hline $\begin{array}{l}\text { other sources of } \\
\text { funding }\end{array}$ & $6,690.2$ & $6,674.7$ & $7,495.5$ & $12,941.3$ & $14,704.7$ & $24,070.2$ \\
\hline
\end{tabular}

The analysis of capital investments by sources (Table 3) shows that within 2014-2019 the key sources are the own funds of enterprises and organizations $(65-71 \%)$, and the funds of foreign investors are only $0.5-3$ percent. We would like to note that significant changes in capital

\footnotetext{
${ }^{11}$ Ibid.

${ }^{12}$ Ibid.
} 
ECONOMIC EUROPEAN INTEGRATION: ASSESSMENT AND MODELLING OF SUPERFICIAL AND HIDDEN FACTORS OF DIVERGENCE BETWEEN UKRAINE AND THE EU

investments were at the expense of local budgets - increase from 3 to 9 percent. This is due to the implementation of the decentralization reform and redistribution of the revenue share of the budget in favour of local budgets. Unfortunately, EU structural funds, EU investment funds, cross-border and infrastructure adjustment funds, which significantly propel the cooperation between underdeveloped and highly developed regions of the EU, were not used in Ukraine, so the GDP recovery rate was too low, the social and economic sector in 2014-2019 was depressed and unstable.

Furthermore, destructive trend is that $2 / 3$ of the total FDI goes the domestic economy sector in Kyiv and Kyiv region. This indicates disbalance and failure to support a balanced social and economic development of Ukraine, which in general does not contribute to internal development and cooperation with EU countries.

Compared to Poland (in 2018-2019 FDI amounted to USD 16-17 billion), Turkey (in 2018-2019 FDI amounted to USD 9-13 billion), Russian Federation (in 2018 - 2019 FDI amounted to USD 9-32 billion), Czech Republic (in 2018-2019 FDI amounted to USD 8-9 billion), Romania (in 2018-2019 FDI amounted to USD $7-7.3$ billion) Ukraine lags significantly in its region in terms of investment attractiveness ${ }^{13}$.

We would like to note that the reason for the low rate of the domestic economy recovery and its difference comparing to EU countries is both insufficient funding from external investors (primarily from EU countries) and the domestic environment, which institutionally cannot accept these investments (weak law enforcement and judicial system, regulated business system, corruption of state bodies, paternalistic society, lack of high moral political establishment and a clear development strategy, poor infrastructure). As a result, the chaos and inconsistency of reforms in Ukraine, absence of clear priorities for strengthening social and economic development, the institutional weakness of public bodies, which introduce a spiral of unsustainable commodity-oriented growth, while neighbouring EU countries (Poland, Estonia, Lithuania) and adjacent countries (Turkey, Belarus) are betting on a more diversified and cutting-edge economy sector, with a prevailing industrial and innovative industries. With this approach, the level of GDP, wages, pensions, wealth of society significantly increases, as evidenced by respective statistic data (Table 4, Table 5, Table 6).

\footnotetext{
${ }^{13}$ The World Bank: Foreign Direct Investment 2019 / URL: http://worldbank.org/
} 
Table 4

GDP OF UKRAINE AND ITS NEIGHBOURS, BILLION USD ${ }^{14}$

\begin{tabular}{|l|c|c|c|c|c|c|c|c|c|}
\hline & 1995 & 2000 & 2005 & 2010 & 2015 & 2016 & 2017 & 2018 & 2019 \\
\hline Belarus & 14.0 & 12.7 & 30.2 & 57.2 & 56.5 & 47.7 & 54.7 & 60.0 & 63.1 \\
\hline Estonia & 4.6 & 5.7 & 14.1 & 19.7 & 23.1 & 24.0 & 26.9 & 30.8 & 31.4 \\
\hline Latvia & 5.8 & 7.9 & 17.0 & 23.8 & 27.1 & 27.8 & 30.3 & 34.3 & 34.1 \\
\hline Lithuania & 7.9 & 11.5 & 26.1 & 37.0 & 41.4 & 43.0 & 47.8 & 53.5 & 54.2 \\
\hline Kazakhstan & 20.4 & 18.3 & 57.1 & 148.1 & 184.4 & 137.3 & 166.8 & 179.4 & 180.2 \\
\hline Moldova & 1.8 & 1.3 & 3.0 & 7.0 & 7.8 & 8.1 & 9.7 & 11.5 & 12.0 \\
\hline Poland & 142 & 172 & 306 & 479 & 478 & 472 & 526 & 587 & 592 \\
\hline $\begin{array}{l}\text { Russian } \\
\text { Federation }\end{array}$ & 396 & 260 & 764 & 1,525 & 1,364 & 1,277 & 1,574 & 1,670 & 1,700 \\
\hline Romania & 37 & 37 & 99 & 166 & 178 & 189 & 212 & 242 & 250 \\
\hline Turkey & 170 & 273 & 501 & 772 & 860 & 864 & 853 & 771 & 754 \\
\hline $\begin{array}{l}\text { Ukraine, Billion } \\
\text { USD }\end{array}$ & $\mathbf{4 8 . 2}$ & $\mathbf{3 1 . 3}$ & $\mathbf{8 6 . 1}$ & $\mathbf{1 3 6 . 0}$ & $\mathbf{9 1 . 0}$ & $\mathbf{9 3 . 4}$ & $\mathbf{1 1 2 . 2}$ & $\mathbf{1 3 0 . 9}$ & $\mathbf{1 5 3 . 8}$ \\
\hline
\end{tabular}

Table 5

RELATIVE COMPARISON OF GDP GROWTH OF UKRAINE, EU AND GLOBAL COUNTRIES TO THE PREVIOUS PERIOD, PERCENTAGE $\%^{15}$

\begin{tabular}{|l|c|c|c|c|c|c|c|c|c|}
\hline & 1995 & 2000 & 2005 & 2010 & 2015 & 2016 & 2017 & 2018 & 2019 \\
\hline Ukraine & $\mathbf{- 1 2 . 2 \%}$ & $\mathbf{5 . 9} \%$ & $\mathbf{3} \%$ & $\mathbf{4 . 2} \%$ & $\mathbf{- 9 . 8} \%$ & $\mathbf{2 . 4} \%$ & $\mathbf{2 . 5} \%$ & $\mathbf{3 . 4} \%$ & $\mathbf{3 . 2} \%$ \\
\hline $\begin{array}{l}\text { EU } \\
\text { Countries }\end{array}$ & $123.2 \%$ & $87.5 \%$ & $164.0 \%$ & $122.1 \%$ & $93.2 \%$ & $102.5 \%$ & $106.1 \%$ & $108.1 \%$ & $97.9 \%$ \\
\hline $\begin{array}{l}\text { Global } \\
\text { Countries }\end{array}$ & $128.9 \%$ & $108.8 \%$ & $141.3 \%$ & $139.1 \%$ & $113.7 \%$ & $101.5 \%$ & $106.4 \%$ & $106.4 \%$ & $101.6 \%$ \\
\hline
\end{tabular}

Table 4 and Table 5 summarize that Ukraine's GDP is lower compared to its neighbours, the relative GDP growth rate comparing to global and

\footnotetext{
${ }^{14} \mathrm{GDP}$ (current US\$) / URL: https://data.worldbank.org/indicator/NY.GDP.MKTP.CD

${ }^{15}$ Ibid.
} 
ECONOMIC EUROPEAN INTEGRATION: ASSESSMENT AND MODELLING OF SUPERFICIAL AND HIDDEN FACTORS OF DIVERGENCE BETWEEN UKRAINE AND THE EU

European countries is mostly lagging behind, Ukraine's GDP shows out-ofstep moving towards global and European trends; in our opinion, this confirms the incorrectly chosen model of social and economic development. In addition, GDP per capita in Ukraine, together with Moldova, is the lowest in the Eastern European region (Table 6). This is due to low labour efficiency, a small share of high-margin goods and services in the GDP of the domestic economy sector. Within the last five-six years, the EU countries have been increasing this indicator more quickly than Ukraine.

Table 6

PURCHASING POWER PARITY GDP PER CAPITA OF UKRAINE AND ITS NEIGHBOURS, USD ${ }^{16}$

\begin{tabular}{|l|c|c|c|c|c|c|c|c|c|c|}
\hline & 1991 & 1995 & 2000 & 2005 & 2010 & 2015 & 2016 & 2017 & 2018 & 2019 \\
\hline Belarus & 5,342 & 3,854 & 5,808 & 9,643 & 15,349 & 18,041 & 17,725 & 18,280 & 19,331 & 19,943 \\
\hline Estonia & 5,400 & 6,460 & 9,437 & 16,625 & 21,809 & 29,397 & 31,231 & 33,821 & 36,358 & 38,811 \\
\hline Latvia & 5,000 & 5,489 & 8,018 & 13,836 & 17,600 & 24,831 & 26,405 & 28,489 & 30,645 & 32,205 \\
\hline Lithuania & 5,100 & 5,922 & 8,460 & 14,526 & 20,054 & 28,823 & 30,925 & 33,821 & 35,832 & 38,214 \\
\hline Kazakhstan & 7,563 & 5,925 & 7,734 & 13,935 & 19,225 & 23,224 & 23,819 & 24,863 & 26,147 & 27,444 \\
\hline Moldova & - & 3,186 & 3,084 & 4,920 & 6,396 & 9,255 & 10,611 & 11,651 & 12,655 & 13,574 \\
\hline Poland & 5,914 & 7,663 & 10,656 & 13,896 & 21,064 & 26,856 & 28,284 & 30,153 & 31,834 & 34,218 \\
\hline $\begin{array}{l}\text { Russian } \\
\text { Federation }\end{array}$ & 7,858 & 5,613 & 6,825 & 11,822 & 20,490 & 24,085 & 24,125 & 26,006 & 28,764 & 29,181 \\
\hline Romania & 4,786 & 5,419 & 5,850 & 9,602 & 16,979 & 21,632 & 24,166 & 27,192 & 29,214 & 32,297 \\
\hline Turkey & 8,738 & 10,383 & 9,586 & 11,887 & 17,439 & 25,626 & 26,329 & 27934 & 28,139 & 27,875 \\
\hline Ukraine & 6,903 & 3,987 & 4,107 & 6,977 & 8,245 & 10,164 & 11,148 & 11,871 & 12,629 & 13,341 \\
\hline $\begin{array}{l}\text { EU } \\
\text { Countries }\end{array}$ & 15,467 & 17,724 & 22,078 & 26,808 & 32,871 & 38,228 & 40,553 & 42,792 & 44,387 & 46,468 \\
\hline $\begin{array}{l}\text { Global } \\
\text { Countries }\end{array}$ & 5,752 & 6,575 & 8,004 & 10,155 & 12,898 & 15,172 & 15,584 & 16,249 & 17,025 & 17,680 \\
\hline
\end{tabular}

Table 6 summarizes that all our neighbouring countries within the EU have lower purchasing power parity GDP per capita than the EU countries in average, but higher than the global countries in average. Only Ukraine and Moldova in the Eastern European region have lower than the global average indices and 3-3.5 times lower than the European average indices.

${ }^{16} \mathrm{GDP}$ percapita, PPP (current international \$) / URL: https://data.worldbank.org/indicator/ NY.GDP.PCAP.PP.CD?end=2019\&locations=KZ-EE-AM-AZ-BY-GE-LV-LT-MD-KG-RU-UA-TJ-TMUZ\&start $=1987 \&$ view $=$ chart 
In 2000-2010, Eastern European EU countries faced the sufficient difference. Within this period, Eastern European countries integrated into the EU in terms of purchasing power parity GDP per capita significantly reduced the gap with other more developed EU countries. In general, our neighbouring EU-members are moving regularly and synchronously with the EU countries, gradually approaching the European average. This indicator significantly affects the society and economy development level, the wealth of the population within the country, the level of wages and pensions. Therefore, we add the study with the level of average monthly wages in Ukraine and its neighbouring countries (Table 7).

Table 7

LEVEL OF AVERAGE MONTHLY WAGES IN UKRAINE

AND ITS NEIGHBOURING COUNTRIES, USD ${ }^{17}$

\begin{tabular}{|l|c|c|c|c|c|c|c|}
\hline & 2013 & 2014 & 2015 & 2016 & 2017 & 2018 & 2019 \\
\hline Belarus & 564 & 590 & 413 & 361 & 422 & 485 & 545 \\
\hline Estonia & 1,259 & 1,270 & 1,200 & 1,150 & 1,313 & 1,480 & 1,560 \\
\hline Latvia & 950 & 970 & 1,100 & 992 & 1,009 & 1,311 & 1,217 \\
\hline Lithuania & 878 & 990 & 1,140 & 1,007 & 903 & 1,660 & 1,419 \\
\hline Kazakhstan & 717 & 645 & 565 & 339 & 432 & 476 & 486 \\
\hline Moldova & 292 & 294 & 244 & 251 & 308 & 408 & 437 \\
\hline Poland & 1,124 & 1,145 & 1,150 & 1,200 & 1,250 & 1,350 & 1,400 \\
\hline $\begin{array}{l}\text { Russian } \\
\text { Federation }\end{array}$ & 936 & 847 & 558 & 547 & 671 & 693 & 788 \\
\hline Romania & 672 & 700 & 800 & 850 & 900 & 990 & 1,100 \\
\hline Turkey & 907 & 980 & 1,050 & 900 & 1,000 & 1,100 & 1,200 \\
\hline Ukraine & $\mathbf{4 0 9}$ & $\mathbf{2 9 3}$ & $\mathbf{1 9 3}$ & $\mathbf{2 0 3}$ & $\mathbf{2 7 3}$ & $\mathbf{3 4 5}$ & $\mathbf{4 6 0}$ \\
\hline
\end{tabular}

Study of the average monthly wages level in Ukraine and its neighbouring countries shows that Ukraine has one of the lowest average wages in the Eastern European region. In 2019, only Moldova had worse indices of average wages. In general, Ukraine $2-3$ times lags behind the most of the key neighbouring countries. This, in turn, causes a significant rate of emigration, moving of top young Ukrainians abroad. The problem of low

\footnotetext{
${ }^{17}$ Developed by the author based on: Average income around the world / URL: https://www worlddata.info/average-income.php; Average wages / OECD /In 2019 constant prices at 2019 USD PPPs/ URL: https://data.oecd.org/earnwage/average-wages.htm; Average annual wages / OECD: current prices / URL: https://stats.oecd.org/Index.aspx?DataSetCode=AV_AN_WAGE \%20; Wages / Trading Economics / URL: https://tradingeconomics.com/country-list/wages
} 
ECONOMIC EUROPEAN INTEGRATION: ASSESSMENT AND MODELLING OF SUPERFICIAL AND HIDDEN FACTORS OF DIVERGENCE BETWEEN UKRAINE AND THE EU

wages is solved by investing in the most promising industries with high added value, which in turn requires significant capital investment in relevant segments, as well as investment in human development, in science, manufacturing, patents, infrastructure. Therefore, Ukraine needs a respective high-tech and high-margin industrial sector development and incentive program at the level of the Cabinet of Ministers of Ukraine and under the supervision of the Ministry for Development of Economy, Trade and Agriculture of Ukraine. The incentive high-profile program should significantly reduce raw materials and agricultural share in the economy sector of Ukraine and regularly shift the industrial production index to positive and long-term growth (as of Q3 2020 it was $93 \%$, i.e. decreased by $7 \%$ to the corresponding period of the previous year).

\section{Forecasting the key economic indicators of Ukraine with unchanged economic policy of the European integration}

Within the last five-six years, Ukraine followed the economic mismanagement model; if it is not changed in future, the forecasts will be also disappointing:

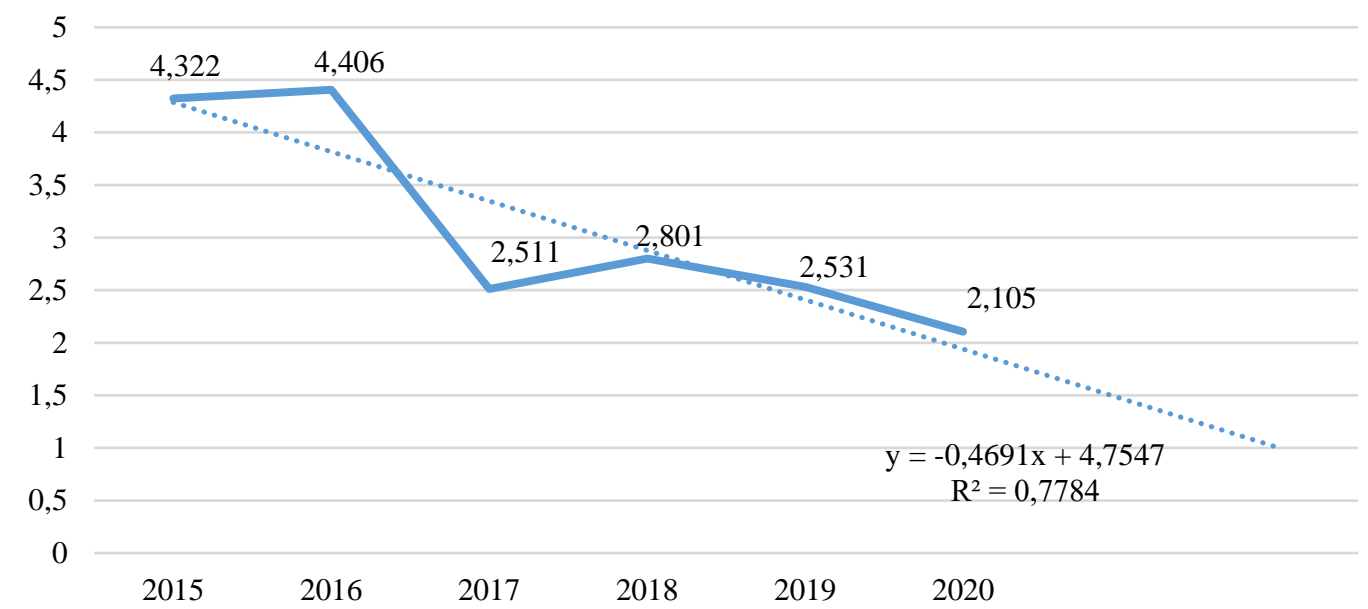

Fig. 1. Forecast of net FDI in Ukraine until 2022 inclusive, billion USD ${ }^{18}$

Figure 1 shows that there is a significant decline in FDI in Ukraine after the signing of the Association Agreement, this is affected by weak institutions, poor personnel policy and the domestic industries' renovation

\footnotetext{
${ }^{18}$ Developed by the author based on the data of the official site of the State statistics service of Ukraine / URL: http://www.ukrstat.gov.ua/
} 
projects. We should also consider the military action's scaring impact on FDI in Ukraine. If such trends continue, the forecast of net FDI in Ukraine in the next two years may fall to USD 1 billion per year. Compared to other countries in the region (Poland, Czech Republic, Slovakia, Romania), these are too low indices for a country like Ukraine.

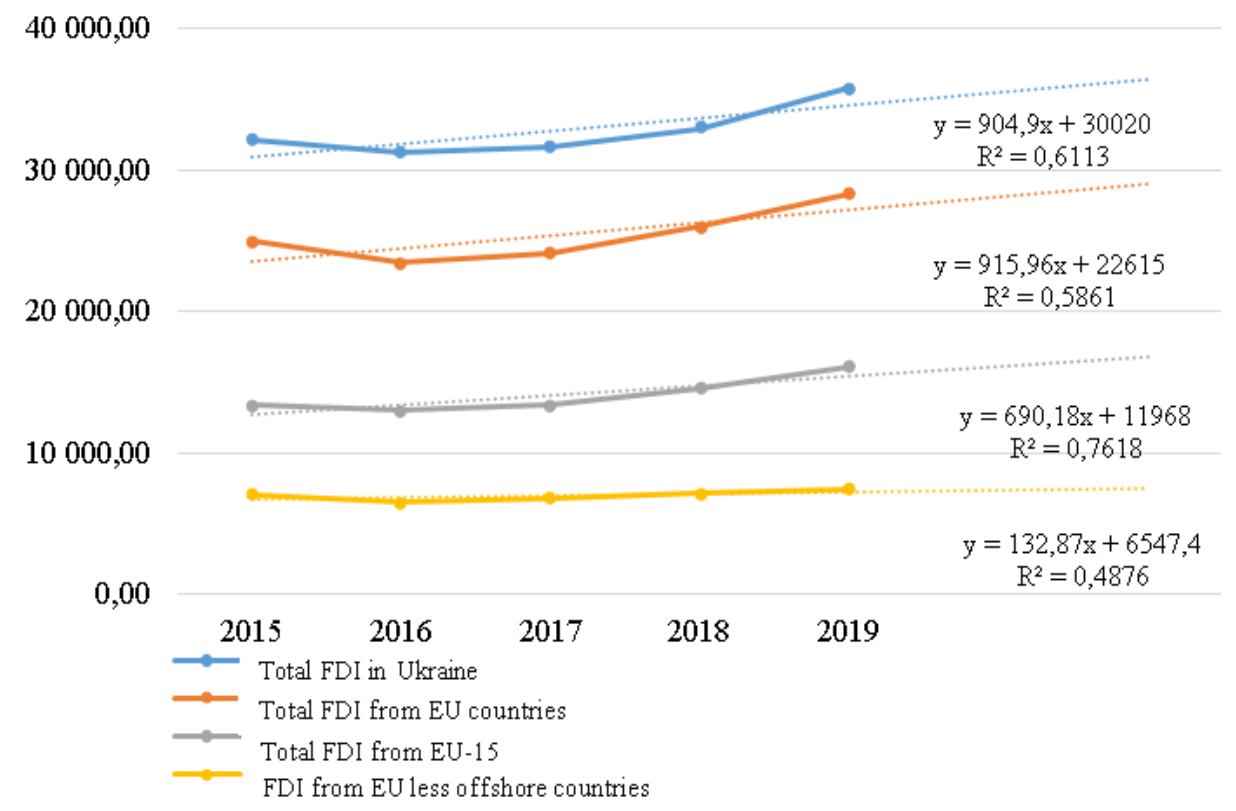

Fig. 2. Forecast of FDI from the global and EU countries in the economy of Ukraine until 2022 inclusive, million USD ${ }^{19}$

Figure 2 summarizes absence of significant increase in investment from both the global and EU countries since the signing of the Association Agreement; the forecast for the next two-three years is not optimistic. All lines of the forecast trend are parallel and no changes depending on the investment donor region are observed. This confirms the significant miscalculations of the Ukrainian government in estimating the opportunities for attracting funds from the global and EU countries in particular. In our opinion, if the current policy on attracting investments based on the best world practices is not subject to crucial changes, the current European integration should not be expected to provide significant FDI to Ukraine's economy sector, which means renewal, growth and prosperity.

\footnotetext{
${ }^{19}$ Developed by the author based on the data of the official site of the State statistics service of Ukraine / URL: http://www.ukrstat.gov.ua/
} 
ECONOMIC EUROPEAN INTEGRATION: ASSESSMENT AND MODELLING OF SUPERFICIAL AND HIDDEN FACTORS OF DIVERGENCE BETWEEN UKRAINE AND THE EU

Figure 3 shows a trend when capital investment in Ukraine at the expense of own funds of enterprises and organizations is gradually increasing, but given that these are par values in hryvnia, they need to be adjusted to the relevant inflation rates within 2014-2019. As a result, it is clear that the current growth of capital investment in Ukraine made by enterprises and organizations is more inflation-driven rather than resultoriented and development trend, which could transform domestic industry to a new level of excellence, efficiency and innovation. In contrast to capital investments at the expense of own funds of enterprises and organizations, which were growing by par value, but were actually stagnant, capital investments in Ukraine at the expense of non-resident investors were generally unstable and decreased significantly, in fact. This failure introduces a lack of interest among foreign investors in the industrial sector of Ukraine. If the current vector is maintained, the forecasts are disappointing, investments will continue to decrease, and the Ukrainian economy sector will become poorer.

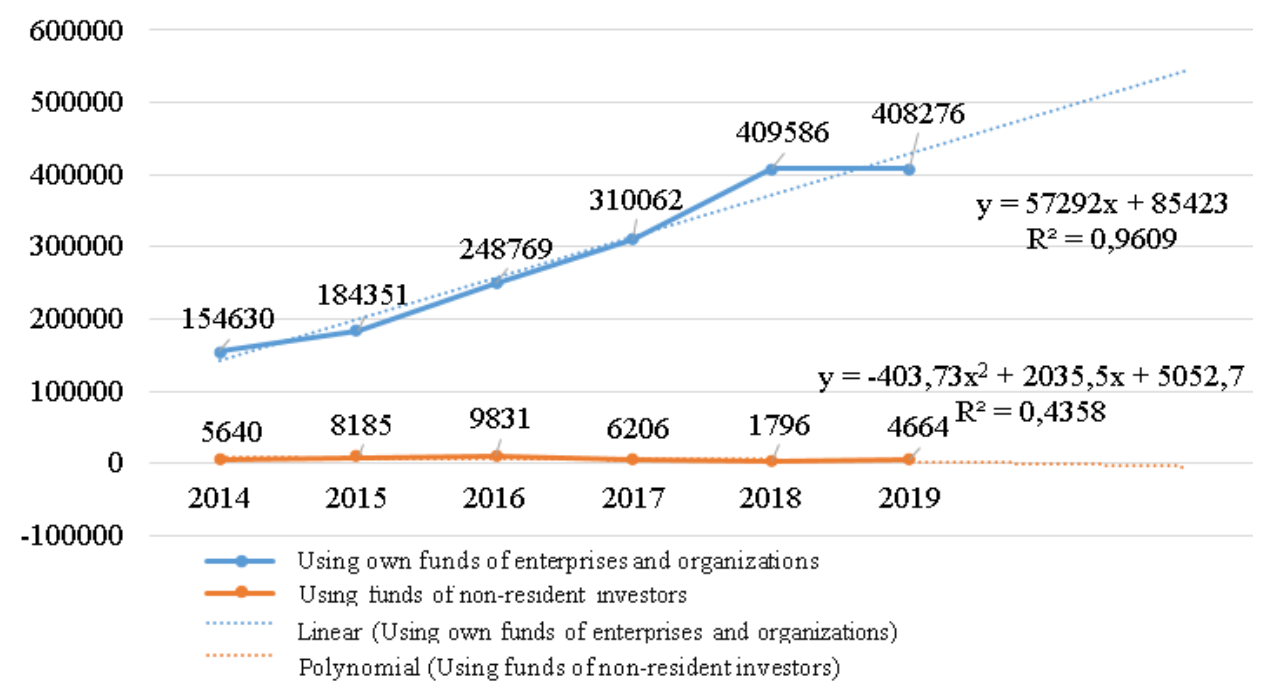

Fig.3. Forecast of capital investments in Ukraine by sources of financing until 2022 inclusive, UAH million ${ }^{20}$

\footnotetext{
${ }^{20}$ Developed by the author based on the data of the official site of the State statistics service of Ukraine / URL: http://www.ukrstat.gov.ua/
} 
Figure 4 summarizes that Ukraine began its reform path when its GDP per capita was higher than the global average GDP, but within twenty-nine years of reforms, the domestic level of GDP per capita has significantly decreased. According to current trends, Ukraine has not caught up these indicators - since 2000, the national GDP per capita regularly decreases and goes in parallel to the global average GDP per capita level. Unfortunately, European integration processes has not moved Ukraine to EU indicators, in particular within the years of Ukraine's independence the gap with EU countries has increased 2-3 times. In addition, it is worrying that this gap keeps on widening and is expected to keep on widening in the coming years.

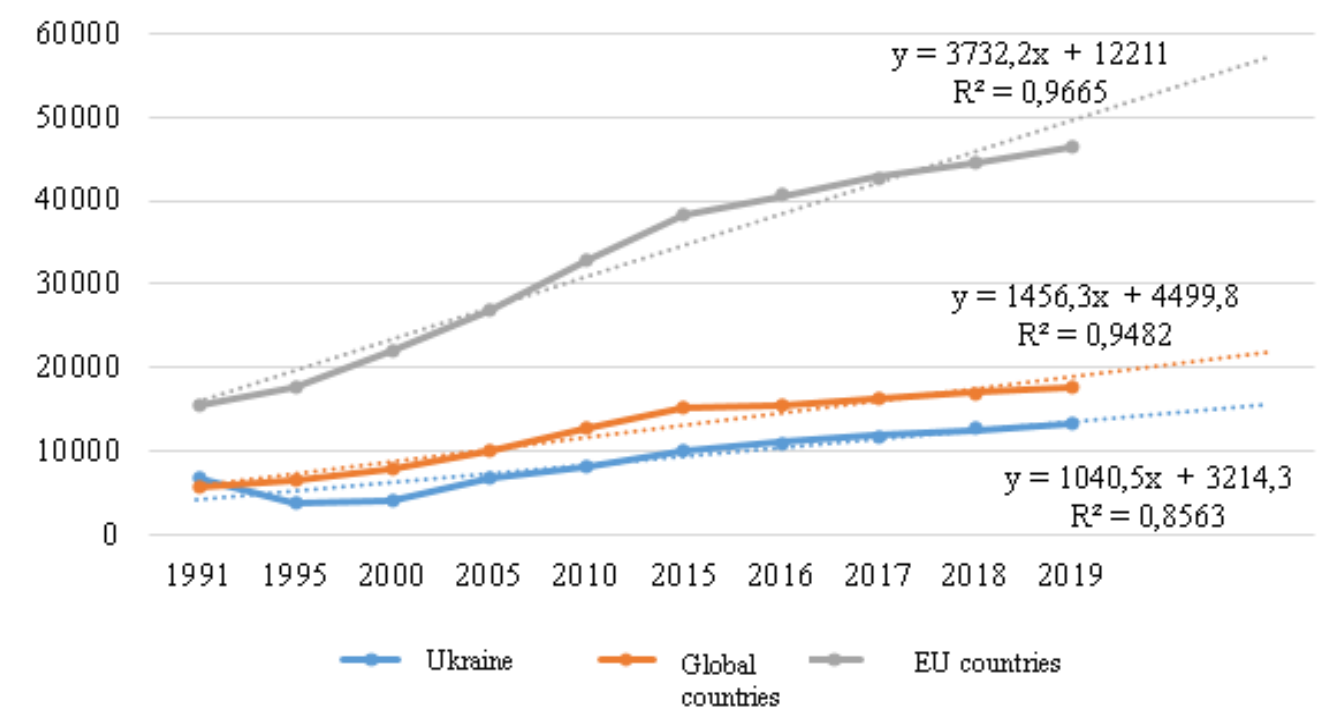

Fig.4. Forecast of purchasing power parity GDP per capita of Ukraine, global and EU countries in the economy of Ukraine until 2022 inclusive, USD ${ }^{21}$

\footnotetext{
${ }^{21}$ Developed by the author based on the data of the official site of the World Bank / GDP per capita, PPP (current international \$) / URL : https://data. worldbank.org/indicator/NY.GDP.PCAP.PP.CD?end=2019\&locations=KZ-EEAM-AZ-BY-GE-LV-LT-MD-KG-RU-UA-TJ-TM-UZ\&start=1987\&view=chart
} 
ECONOMIC EUROPEAN INTEGRATION: ASSESSMENT AND MODELLING OF SUPERFICIAL AND HIDDEN FACTORS OF DIVERGENCE BETWEEN UKRAINE AND THE EU

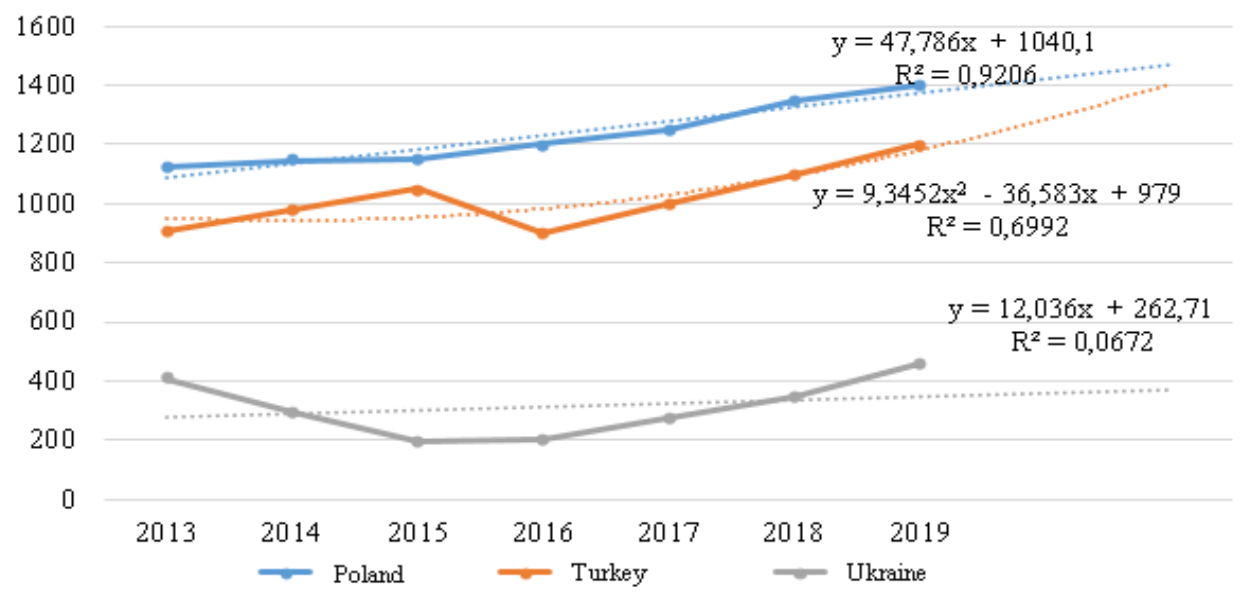

Fig.5. Forecast of the level of average monthly wages in Ukraine and its neighbouring Poland and Turkey until 2022 inclusive, USD ${ }^{22}$

Figure 5 shows that the level of average monthly wages in Ukraine and the key partner countries in the region significantly differs. Thus, domestic wages are 3-3.5 times lower than in Poland; in Turkey -3 times lower. In 2013, this gap was smaller -2.8 and 2.2 times. At the same time, the level of $\mathrm{R}$ reliability for Ukraine is very low, which confirms that this indicator is instable and can significantly decrease, in particular during crises in the global economy, or during domestic social and political or financial and economic crises. Actual trends in 2020 show that average wages in the domestic business sector are declining, and the crisis, namely at the level of small and medium-sized businesses, is significantly growing. Therefore, the prospects for further growth of average monthly wages in Ukraine, with due consideration to inflation rate, are under threat. In addition, there are no strong reasons for narrowing the wage gap between Ukraine and its neighbouring countries, unfortunately.

In general, over the last five-six years, the Ukrainian economy sector, despite the gradual strengthening of cooperation with the EU, has significantly increased its dependence on raw materials, failure trends,

${ }^{22}$ Developed by the author based on the data: 1) Average income around the world / URL : https://www.worlddata.info/average-income.php; 2) Average wages / OECD /In 2019 constant prices at 2019 USD PPPs/ URL: https://data.oecd.org/earnwage/average-wages.htm; 3) Average annual wages / OECD: current prices / URL: https://stats.oecd.org/Index.aspx?DataSetCode=AV_AN_WAGE \%20; 4) Wages / Trading Economics / URL: https://tradingeconomics.com/country-list/wages 
reduced a significant amount of high and medium-tech production; in particular, this process was much influenced by the signing of the Association Agreement and the break-up with the CIS countries. However, the EU remains Ukraine's key trading partner, accounting for 42 percent of our country's total trade volumes, with a negative ratio between imports and exports not in Ukraine's favour. The total trade turnover between the EU and Ukraine reached about EUR 40 billion in 2018, it is almost $9 \%$ increase compared to 2017; and in 2019 - up to EUR 43.3 billion, it is almost $8 \%$ increase compared to 2018. Ukraine is the EU's 21st largest trading partner. In 2018-2019, Ukraine mainly exported metals and metal products (21.9 percent of the total), plant products (18.9 percent), mineral products (15.0 percent), machinery and devices (11.8 percent). The trade changes are shown in Table 8.

Table 8

TRADE IN GOODS BETWEEN UKRAINE AND EU-28, MILLION EUR ${ }^{23}$

\begin{tabular}{|l|c|c|c|c|c|c|c|}
\hline & 2013 & 2014 & 2015 & 2016 & 2017 & 2018 & 2019 \\
\hline Total trade volume & 37,781 & 30,729 & 26,877 & 29,749 & 36,877 & 40,085 & 43,320 \\
\hline Imports from EU-28 & 23,899 & 16,995 & 14,033 & 16,568 & 20,194 & 22,065 & 24,203 \\
\hline Exports to EU-28 & 13,882 & 13,734 & 12,844 & 13,182 & 16,683 & 18,019 & 19,117 \\
\hline Balance & $-10,017$ & $-3,262$ & $-1,190$ & $-3,386$ & $-3,511$ & $-4,046$ & $-5,086$ \\
\hline
\end{tabular}

The situation with trade in services between Ukraine and the EU is also similar: in 2016 - EUR 5.4 billion imports, EUR 2.5 billion exports, balance - EUR 2.9 billion; 2017 - EUR 6.6 billion imports, EUR 2.7 billion exports, balance EUR -3.8 billion; 2018 - EUR 7.1 billion imports, EUR 2.9 billion exports, balance - EUR 4.2 billion. In total, a negative balance of trade in goods and services with EU countries, if this trend continues, may threaten Ukraine's economic security.

\footnotetext{
${ }^{23}$ Developed by the author based on the data: Representation Office of the European Union in Ukraine / Summary of trade statistics. URL:https://eeas.europa.eu/delegations/ukraine/10781/\%D1\%83\% ... _uk [In Ukrainian]; European Commission / Trade / Policy / Countries and regions / Ukraine. / URL: https://ec.europa.eu/trade/ policy/countries-and-regions/countries/ukraine/
} 
ECONOMIC EUROPEAN INTEGRATION: ASSESSMENT AND MODELLING OF SUPERFICIAL AND HIDDEN FACTORS OF DIVERGENCE BETWEEN UKRAINE AND THE EU

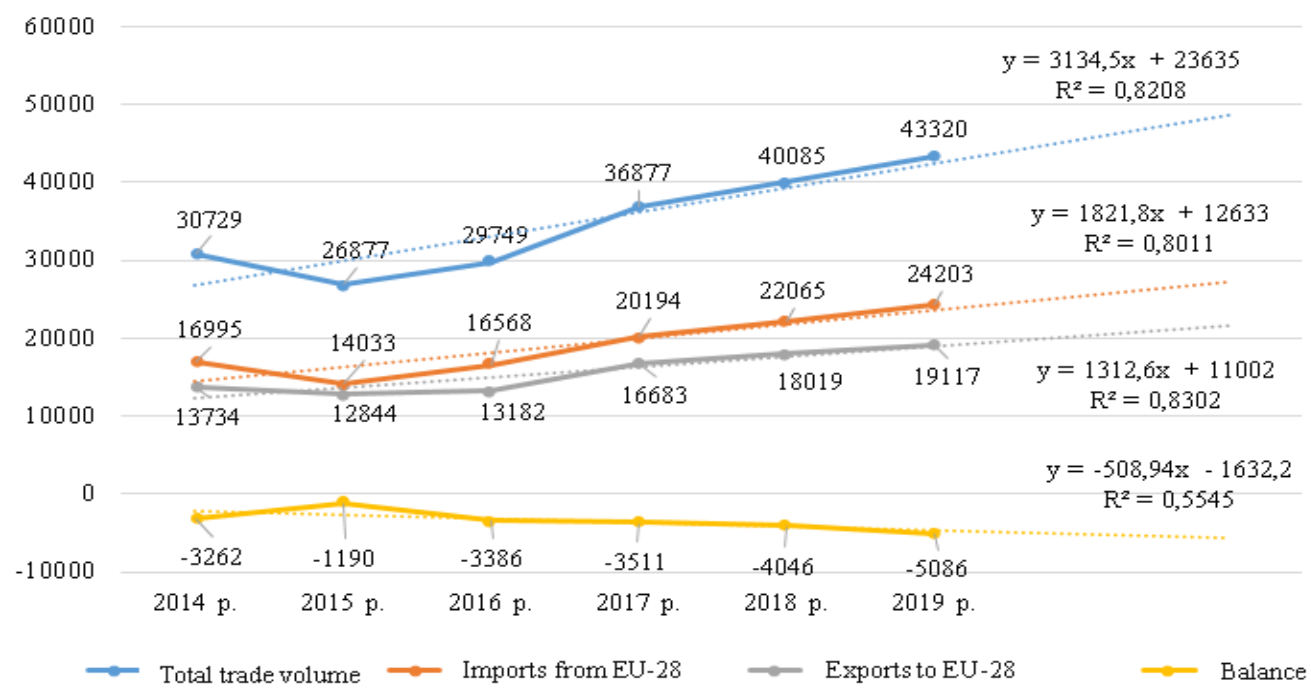

Fig. 6. Forecast of trade in goods between Ukraine and EU-28 until 2022 inclusive, million EUR ${ }^{24}$

Figure 6 summarizes that the growth rate of imports from EU countries is gradually increasing and the growth rate of EU exports prevails. With this trend unchanged in the coming years, according to the author, in $2-3$ years the domestic economy is very likely to expect another wave of hryvnia devaluation and decline in the wealth of citizens due to significant growth in imports and cut-off of domestic production of high value added goods.

\section{Critical factors influencing the convergence trends between the countries of Central and Eastern Europe and the developed countries of the EU}

We would like to note that EU membership and accession prospects have increased the economic attractiveness of Central and Eastern European (CEE) countries both for other EU countries (largely due to joining the European value chains, CEE countries have achieved progress vs Ukraine) and other global countries, for example, by reducing risk premiums. Joining the group of highly developed countries with stable institutions ensures a long-term support for reliable investment climate and trading partners in CEE countries; this attracted a significant number of companies from other

\footnotetext{
${ }^{24}$ Developed by the author based on the data: 1) Representation Office of the European Union in Ukraine / Summary of trade statistics. URL:https://eeas.europa.eu/delegations/ukraine/10781/\%D1\%83\% ... _uk [In Ukrainian]; 2) European Commission / Trade / Policy / Countries and regions / Ukraine / URL: https://ec.europa.eu/trade/policy/countries-and-regions/countries/ukraine/
} 
parts of the world outside the EU to build up and develop business relationships. Making efficient steps, CEE countries combine the attractiveness of developing countries (high marginal return on capital, cheap labour, which at the same time is well prepared due to a good education practice) with the institutional strength of advanced European countries. Therefore, trade and GDP growth between CEE countries and other global countries strongly increased compared to developed EU countries. Such countries, first of all, include Poland, Czech Republic, Slovakia and Estonia.

CEE countries have significantly increased their output upon accession to the EU, not only through grabbing the common market, but also through direct financial tranches and pre-accession aid. In addition, as EU members, they have gained access to infrastructure funds, direct payments in agriculture, cross-border cooperation funds, and other EU structural funds. These investment and transformation channels much contributed to the benefits for CEE countries from European integration ${ }^{25},{ }^{26}$.

The current trend of post-crisis recovery in Europe will be based on a strategy of sustainable growth, which launches a recovery cycle based on: environmental sustainability, production efficiency, fair play, macroeconomic reliable trends. Significant investments in the EU will be made in green and digital technologies. Here, Ukraine is technically backward, raw materials-oriented, energy-consuming and low-environment economy sector does not fit into the EU's future development strategy ${ }^{27}$.

\section{Potential, opportunities and Ukraine's priority measures for overcoming the divergence with $\mathrm{EU}$ countries}

In our opinion, given the existing domestic limitation and resources the IT industry may be the segment with the lowest possible expenditures of the state budget and the greatest return (economic driver). Thus, such segments as production of information and software products and services, communication and transmission and entertainment technologies, services, research and development of artificial intelligence, industrial robotics and digitalization, IT offshoring and IT outsourcing, etc. under certain conditions can be significantly developed and integrated both with EU and global countries. There is a global growing demand for IT services; therefore, the IT sector can be an integrative platform of transition to a high-tech economy sector in Ukraine. Existing domestic strengths (primarily labour force and

\footnotetext{
${ }^{25}$ Mann, Katja (2015): The EU, a Growth Engine? The Impact of European Integrationon Economic Growthin Central Eastern Europe, FIW Working Paper, No. 136, FIW - Research Centre International Economics, Vienna / URL: https://www.econstor.eu/bitstream/10419/121136/1/N_136.pdf

${ }^{26}$ PascalBlanque, AminRajanHowdoinvestorsviewthefutureofthe EU economy? / IPE magazine / December 2018. URL: https://www.ipe.com/how-do-investors-view-the-future-of-the-eu-economy/10028240.article

27 Recovery from the coronavirus // The Recovery and Resilience Facility / European Commission.URL:https://ec.europa.eu/info/business-economy-euro/recovery-coronavirus_en
} 
ECONOMIC EUROPEAN INTEGRATION: ASSESSMENT AND MODELLING OF SUPERFICIAL AND HIDDEN FACTORS OF DIVERGENCE BETWEEN UKRAINE AND THE EU

other resources) need to be used and regularly developed, with no need for big investments in the development of large-scale industrial projects. EU countries have strong position on developing new and existing IT technologies, IT products, services and programs; therefore, they invest a lot of money through various programs and funds. Thus, the Future \& Emerging Technologies (FET) programme provides over EUR 700 million funding ${ }^{28}$. With the above said, in our opinion, it would be reasonable to introduce at the state level a more strong diplomatic position on Ukraine's involvement in digital technology development sector in Europe, and at the level of the Ministry of Digital Transformation of Ukraine, the Ministry of Education and Science of Ukraine and the Ministry of for Development of Economy, Trade and Agriculture - to promote the private sector to be involved in these funds and programs, to hold regular targeted scientific and educational events, to develop the relevant staff resources and infrastructure.

In addition, at the highest state level it is necessary to update the existing Free Trade Agreement with EU countries to adjust all standards and get rid of various restrictions (especially non-tariff restrictions), to unblock funding from EU structural funds, to make adjustments using EU funds (mutual funds, partnership funds, infrastructure assistance funds), to attract grant funds for infrastructure development and support better conditions for them than in our neighbouring countries - to encourage leading European companies to transfer their production facilities from Russia, China, Belarus, the Baltic countries, Turkey to Ukraine. Supply logistics and wages contribute to this process, but Ukraine cannot clearly and regularly introduce its investment attractiveness by getting rid of negligence, over-regulation, corruption, and conservatism to change.

The lack of progress in medium- and high-tech cooperation between Ukraine and the EU is supported by the idle opportunities as for the Agreement on Conformity Assessment and Acceptance of Industrial Products (ACAA). ACAA belongs to the type of agreements on mutual recognition of assessments of compliance with regulations. Such agreements mean that countries mutually recognize the working records of conformity assessment bodies, i.e. the certificates issued by these bodies. The Association Agreement with the EU provides for the possibility of its signing, but Ukraine has not yet done it, and therefore reduces the industrial and technical strength of the domestic economy sector in cooperation with EU countries ${ }^{29}$.

In our opinion, measures to promote the development of high-tech sectors of Ukraine's economy should include a comprehensive strategic program:

\footnotetext{
${ }^{28}$ Future \& Emerging Technologies (FET) // European Commission. URL: https://ec.europa.eu/digital-singlemarket/en/future-emerging-technologies-fet

${ }_{29}$ Movchan V. «Promyslovyi bezviz» iz YeS / Dzerkalo tyzhnia. (2020). - No. 4. URL: https://zn.ua/ukr/macrolevel/promislovij-bezviz-iz-jes.html [In Ukrainian].
} 
1) development of a favourable business environment (improvement of the rule of law in Ukraine, strengthening control over "grey" and "black" imports, improving the system of state regulation, reducing the domestic economic expenses and business risks);

2) introduction of tools of mutually beneficial distribution of imported products and solutions in public procurement;

3) increase in public investment in human capital and attraction of private capital and youth to cutting-edge economy sectors;

4) introduction of a tax on "obsolete" and faulty technologies (Japanese experience), involvement of the practice of budget redistribution of funds from rental and raw materials fields in the IT segment, in the innovation sector, in science and education, in the high-tech industrial sector of the domestic economy;

5) development of innovation and industrial parks with the best up-todate infrastructural capabilities;

6) regulatory adjustment of Ukrainian legislation with the relevant regulations of the EU countries;

7) introduction of a practice of preferential crediting and insurance of domestic producers producing industrial, innovative and IT products for export, etc.

In Ukraine, without a production and supply logistics partnership and without involvement in the existing most powerful global economic centres, the domestic social and economic environment will continue to come down and be exposed to the risks of a globalized economy. We'd like to note that Poland's largest trading partners (which exports share is over 60 percent in vehicles, machinery, equipment, devices, electrical appliances) are Germany, France, Great Britain, Czech Republic, China, Italy, Russia, the Netherlands, while Ukraine's share is only $2-2.5$ percent; Ukraine is not even among the top 10 trading partners. Therefore, a new realistic program of cooperation with EU countries based on the pragmatic concept (and not only with them) is needed, with due consideration to the high-tech and highmargin sectors, which ensure wealth and social strength in modern countries.

With this in mind, the Ukrainian leadership needs to significantly rethink the existing opportunities and patterns of domestic economy rent-oriented and low-efficient for society and contemporary civilization in order to direct it in those fields and sectors that would help Ukraine's economy to have a sustainable vector of innovation and industrial development. However, we must also consider that Ukrainian economy significantly suffers from a toxic influence of oligarchic groups, and investments are blocked by corrupt officials and low standards of property rights protection. Only with comprehensive resolution of these issues, the domestic economy sector will 
ECONOMIC EUROPEAN INTEGRATION: ASSESSMENT AND MODELLING OF SUPERFICIAL AND HIDDEN FACTORS OF DIVERGENCE BETWEEN UKRAINE AND THE EU

be able to implement its opportunities in full and in line with the EU economy ${ }^{30}, 31,32$.

\section{Conclusions}

With the above said, we would like to note that the system-based dynamic modelling study showed a significant backwardness of Ukraine from the key macroeconomic indicators compared to the EU countries. The dependence on EU GDP growth and the insignificant impact of Ukraine's GDP growth is explained by the difference in the scale of the EU and Ukrainian economies (as evidenced by the gravity model of foreign trade relations). The exports and imports pattern in bilateral trade and economic relations between Ukraine and the EU introduces a dangerous technological imbalance for the domestic economy: raw material imports from Ukraine and high-tech EU exports; maintaining a negative balance in foreign trade for the most groups of goods; limited access of domestic businesses to the EU market due to the high level of non-tariff protection, primarily for agricultural products. Extremely low level of private investment from individuals and legal entities from EU countries, lack of regular grant investment from EU structural funds, EU investment funds, cross-border and infrastructure equalization funds, which significantly promote convergence between underdeveloped and highly developed regions of the EU - in Ukraine leads to stagnation and divergence. This is confirmed by a significant reduction in FDI in Ukraine's economy within $2017-2020$. Therefore, it is advisable to rethink reforms, focus on policies to effectively attract investment to Ukraine's economy sector, introduce a respective program promoting and developing Ukraine's high-tech and high-margin industrial sector, with the initial priority to focus the leading resources on the development of IT sector, which would be a part of the EU's digital transformation strategy. The policy of involving European producers in building in or transferring their production facilities to Ukraine on a mutually beneficial basis also needs to be updated. In our opinion, Ukraine faced the unreasonably high expectations of Ukraine's leadership within 2014-2019 from the Association Agreement, the lack of a clear and realistic strategy of cooperation with EU countries, as well as: high level of competition in the European market; efficient value chains in Europe that

${ }^{30}$ Redziuk Ye. V. Formuvannia efektyvnoho finansovo-investytsiinoho seredovyshcha v krainakh YeS — dosvid dlia Ukrainy / Problemy innovatsiino-investytsiinoho rozvytku.(2019). — No. 20. — S.4-13. [In Ukrainian].

${ }^{31}$ Shnyrkov O. O., Ivkova N. I. Porivnialna kharakterystyka vnutrishno haluzevoi torhivli Ukrainy z YeS za indeksom Hrubelia-LLoida / Aktualni problemy mizhnarodnykh vidnosyn. (2018). — Vypusk 136. - S. 84-92. [In Ukrainian].

${ }^{32}$ Yablonski L., Yablonski M., Fedirko O. A. Formuvannia ekonomiky znan v YeS: metodolohichni zasady ta mekhanizmy implementatsii. / Mizhnarodna ekonomichna polityka. — Tom 2. No. 2 (29). (2018). - s. 7-36. [In Ukrainian]. 
do not require additional chains and resources other than raw materials and cheap labour; the restrictive rules, quotas, tariffs and complex procedures for admission to the common internal EU market; strengthening disintegration steps and political representation in the EU; scepticism policy on further enlargement and reluctance to include new members in the European community.

\section{References}

1. Vlasyuk $V$. Ekonomichne vidrodzhennya cherez industrialnij rozvitok Ukraini. - Kharkiv: Povnokolir, 2020. - 432 p. [In Ukrainian]

2. Balezhentis A., Yatsenko O. Asimetrii torgovelnoi integratsii Ukraini ta ES Mizhnarodna ekonomichna politika.- 2018. - No. 1 (28). - pp. 32-62. [In Ukrainian]

3. Lukianenko D., Chuzhykov V., Wozniak M., Antoniuk L.Convergence and DivergenceinEurope: Polish and Ukrainian Cases / Monograph. - K.: KNEU. 2013. - 688 p.

4. Mann, Katja (2015): The EU, a Growth Engine? The Impact of European Integration on Economic Growth in Central Eastern Europe, FIW Working Paper, No. 136, FIW - Research Centre International Economics, Vienna. URL: https://www.econstor.eu/bitstream/10419/121136/1/N_136.pdf

5. Pascal Blanque, Amin Rajan. How do investors view the future of the EU economy? / IPE magazine / December 2018, available at: https://www.ipe. com / how-do-investors-view-the-future-of-the-eu-economy / 10028240.article

6. MovchanV. «Promisloviibezviz» iz ES /Dzerkalotizhnya. - 2020. - No. 4. URL: https: / / zn.ua /ukr / macrolevel/promislovij-bezviz-iz-jes.html. [In Ukrainian].

7. Redzyuk Y.V.Formuvannyaefektivnogofinansovo-investitsijnogoseredovishcha v krainakh ES - dosviddlyaUkraini Problemi innovatsijno-investitsijnogo rozvitku. Naukovo-praktichnijzhurnal. 20/2019. - K.: Milenium, 2019. - pp. $4-$ 13. [In Ukrainian]

8. Shnirkov O. O., Ivkova N. I. Porivnyalna kharakterystyka vnutrishnogaluzevoi torgivli Ukrainy z ES za indeksom Grubelya-Lloida / Aktualni problemi mizhnarodnikh vidnosin. - 2018. - Vypusk 136. - pp. 84-92. [In Ukrainian]

9. Yablonski L., Yablonski M., Fedirko O. A. Formuvannya ekonomiki znan' v ES: metodologichni zasadi ta mekhanizmi implementatsiï. / Mizhnarodna ekonomichna polityka. - Tom 2. No. 2 (29). (2018). - pp. 7 -36. [In Ukrainian].

The article was received by the Editorial Board on March 23, 2021. 